\title{
The influence of the domestic election cycle on the turnout for Euro- pean parliamentary elections. The case of Poland
}

\begin{abstract}
The purpose of the article is to diagnose the causes of the increased interest shown by Poles in the European parliamentary election in 2019. From 2014 to 2019, Poles' participation in elections to the European Parliament went up from $23.83 \%$ to $45.68 \%$. Drawing on Europe salience theory and second-order election theory, I set out to determine whether changes in Poles' attitudes towards the European Union led to this almost twofold increase in turnout from 2014 to 2019, or whether this trend was mainly attributable to the election cycle, that is, the coincidence in 2019 of both European and domestic parliamentary elections. My research involved an analysis of survey data (CBOS, Eurobarometr), statistical data, and the course of the European parliamentary election campaign.

During the analysis, it turned out that in the years 2014-2019 there were no significant changes in how the European Union and its institutions were perceived by Poles that could explain the dramatic increase in interest in the European election. What had the greatest impact on voter behaviour was the fact that the European election was held just several months before an election to the Polish parliament. The Polish political parties treated the European election in May as a test of support in the nation election to be held in the autumn - as a 'quasi-first round.' The European election campaign was heavily covered by the media, and focused on domestic issues (building up Poland's welfare state). The ruling party's announcement of numerous social reforms and a desire to influence the result of the 'May round' mobilised an above-average number of Poles to take an active part in the European election.
\end{abstract}

Key words: turnout, elections, European Parliament, Poland, election campaign

\section{Introduction}

$\mathbf{T}$ he subject of this analysis is the increased participation of Poles in the election to the European Parliament (EP) in 2019. Since the first EP election, the turnout in Poland had been very low. In 2004, it was $20.87 \%$, and remained at a similar level in subsequent elections: $24.53 \%$ in 2009 and $23.83 \%$ in 2014 . These results were about half of the average for the European Union as a whole, and left Poland in last places among all EU Member States in this respect (Results..., 2014; 2019 European ...).

A lower turnout for EP elections than for domestic parliamentary or presidential elections is typical of EU Member States. This is because the stakes in the political game are lower (the executive branch is not elected). The motivation of the electorate to take part in these elections is weaker. For this reason, European parliamentary elections are classified in the literature as second-order elections (Donatella, 2015, p. 41). It is expected that EP elections will interest citizens more when the decision-making power of the European Parliament is increased (Rachwał, 2017, p. 71). Empirical research also reveals that citizens who support European integration are more willing to vote in European elections than are those who hold the opposite viewpoint. Another relationship that has 
been observed is a higher rate of participation in European elections in those countries that obtain more EU assistance from, for example, structural funds, and in those countries that have a higher rate of support for EU membership (Hix, Marsh, 2007, p. 497).

From 2014 to 2019 no political reform of the EU took place, nor were the competencies of the EP enlarged, yet in Poland in 2019 the turnout for the European parliamentary election increased substantially $-45.68 \%$ of eligible voters cast a ballot for their representatives. This increase in voter turnout over the year 2014 was $91.69 \%$, the largest increase recorded for any EU Member State in the 2019 election (2019 European...). One effect of this was that Poland advanced from 26th place among EU Member States in terms of EP election voter turnout to 15th place. Further, the 'European gap', that is, the difference in turnout between domestic and European parliamentary elections, went down from 25.09 percentage point in 2014 to $5.24 \%$ percentage point in $2019 .{ }^{1}$

In the earlier EP elections (in 2004, 2009 and 2014) the Polish government comprised groupings that were favourably or neutrally disposed towards Poland's EU membership and further European integration (in 2004 this was a coalition of two left-wing parties - the Democratic Left Alliance (SLD) and the Union of Labour (UP), and in 2009 and 2014 a coalition of the centrist-liberal Civic Platform (PO) and the rural-based Polish People's Party (PSL)), and in the public media a positive image of the EU dominated. During this period, Poland was the largest beneficiary of EU cohesion policy, and Poles were among the most ardent enthusiasts of any EU society for the process of integration. Nevertheless, the turnout for European elections in Poland was consistently one of the lowest in the EU.

Importantly, the big jump in turnout took place after four years of government by the Law and Justice party (PiS), which has a clearly euro-sceptic profile and treats Poland's membership in the EU instrumentally (primarily as a source of EU funds). In this period, the narration about the EU given in the public media also changed, after 2015 the public media became subordinated to PiS. The existing euro-enthusiasm gave way to euro-hostility (felt particularly keenly in the disputes between Brussels and Warsaw over reform of the Polish judiciary). Under these circumstances, the high level of participation of Poles in the European election in 2019 becomes even more intriguing.

The first part of this article discusses theories that explain levels of participation in elections. Particularly attention is paid to second-order election theory and Europe salience theory as research approaches that refer directly to European elections. They form the basis for the research hypotheses put forward. The next part of the article contains an analysis of public opinion surveys showing Polish attitudes towards the EU in the years 2014-2019. The final part discusses the European parliamentary election campaign in Poland in 2019.

\section{Voter turnout in light of existing research}

In the literature on the subject, the factors that affect the level of participation in elections are usually divided into institutional, contextual and individual factors. The

1 These calculations were based on the turnout for the elections to the Polish parliament preceding the 2019 EP election, i.e. from 2011 and 2015. 
first group, which relates to constitutional norms, the political system, the party system, electoral law and so on, has the greatest impact on voter turnout. The rate may be higher or lower depending on whether citizens have a constitutional duty to take part in elections or to register early, whether postal voting is allowed, or voting by proxy, e-voting or advance voting, whether a majority or proportional formula applies under electoral law, and whether elections are held on weekdays or weekends. In the case of European elections, a further institutional factor that increases participation is when voting is connected with national elections. ${ }^{2}$

Contextual approaches explain election turnout by the social, political and economic context in which voters live. In the first of these, the level of citizens' political culture is of key importance. ${ }^{3}$ Equally important is the supply side of politics, that is, how attractive political parties' offers are. The political context includes the character of the election campaign. A wide-ranging election campaign increases people's interest in participating in the election (theory of political mobilisation). In respect of European elections, the approach of the media to European issues is also vital. The combination of the low interest shown by political parties in running European election campaigns (in terms of both resources and time) and the low quality of media reporting on EU issues leads to reduced interest in European elections among voters, creating what is known as a 'triangle of apathy' (Gasser, 2019). The economic situation in a country (e.g. the unemployment rate), and even the time of year or the weather on election day, can all affect turnout.

The research approach that seeks to explain citizens' involvement in the election process by individual factors is mainly based on voters' individual attitudes towards politics. In the case of EP elections, a low turnout may be interpreted as a result of voters having little knowledge about the elections and the competences of the European Parliament, or of their being little interested in politics overall - and particularly at the EU level. Sociodemographic factors such as sex, age, civil status, education, socio-economic position and occupation may also be studied, since these also affect citizens' participation in elections (life cycle theory, individual resources theory, rational choice theory) (Grzelak, Cześnik, 2007, pp. 5-7; Aksztejn 2006, pp. 51-59; Sześciło, Cześnik, Markowski, 2013, pp. 19-21, 90, 97-107).

Research approaches that refer strictly to European elections add further variables to this set. In accordance with the second-order elections model, for national political parties elections to the European Parliament constitute a mid-term test of support on the road to gaining power in national elections. Long-term studies of the nature of European elections show that first-order elections (national parliamentary or presidential elections)

${ }^{2}$ In 2004, 2014 and 2019, in Lithuania the European elections were held together with presidential elections. The turnouts for those elections were $48 \%, 47.3 \%$ and $53.48 \%$ (Sondaż..., 2014, p. 7; Hyndle-Hussein 2014). In 2009, when the EP election was held at a separate time, the turnout was 21\% (Rachwał 2017, p. 67).

${ }^{3}$ In the case of Poland, lower turnout for European elections has usually been attributed to Poles' low level of participation in national elections and the lack of a tradition of voting in EP elections. In Polish national parliamentary elections, the turnout has exceeded $60 \%$ only twice: in $1989(62.7 \%)$, and in $2019(61.7 \%)$. The greatest interest is shown in presidential elections, where the turnout has exceeded $60 \%$ on four occasions (in $1990-60.6 \%$, in the first and second rounds in $1995-64.7 \%$ and $68.2 \%$, respectively, in $2000-61.1 \%$, and in the first and second rounds in $2020-64,51 \%$ and $68.18 \%$, respectively) (Cześnik, Kwiatkowska 2017, p. 32; PKW, 2020). 
have an impact on EP elections, even when, formally, the latter revolve around different issues. The behaviour of voters in European elections is a reflection of the positive or negative moods that form with regard to their domestic political situation. In effect, voters use European elections to manifest their support for or dissatisfaction with the governing political party at home (Marsh 1998, p. 592; Hix, Marsh, 2007, p. 495).

An important assumption of second-order election theory, therefore, is that the voter turnout in European elections and the amount of support shown for the governing party in those elections is connected with the national election cycle. Several regularities exist here. When an EP election is held just after national parliamentary elections, this usually results in a decline in the EP election turnout and a rise in support for the governing party. This is related to what is known as the 'honeymoon effect': voters carry their support for the victors in the recent national parliamentary election over to the European election. In turn, when a European election falls just before a national election, this usually causes a larger turnout. This is so because participants in the national election campaign are more strongly motivated to engage more resources in preparing their Euro campaign. Political parties use it to test their chance of winning the national election, which for them is the most important contest. Citizens are also better motivated to vote, because they want to have an effect on the upcoming domestic election. A European election held in the middle of the national election cycle is the least advantegous for the ruling party, for it leads to the biggest drop in the support it receives (Hix, Marsh, 2007, p. 496).

Competing against second-order election theory is Europe salience theory. Whereas second-order theory treats European issues as an insignificant variable in studies of fluctuations in election turnouts, Europe salience theory considers them to be a strategic variable. It has been shown that what is going on in the EU, and what the attitudes of national political elites and voters towards the EU are, have a significant effect on the turnout for European elections. In accordance with this theory, the turnout in a European election depends on such factors as citizens' knowledge about the EU, their trust in the EU, the position taken by the government towards European integration, location of EU institutions in the country, citizens' feeling of European identity, and how highly developed agricultural sector is in the country (Donatella, 2015, p. 45).

\section{Goal of the research}

The goal of this article is to diagnose the causes of the increased interest shown by Poles in the 2019 European parliamentary election (turnout almost doubled). I will try to show which research approach best explains this phenomenon. I will consider whether, in accordance with Europe salience theory, factors of a European provenance led to the increased participation of Poles in the EP election. I will also consider whether, in line with second-order election theory, the change is better attributed to the election cycle, that is, the fact that the European election took place half a year before national parliamentary elections.

Guided by the assumptions of Europe salience theory, my first hypothesis is that the mass mobilisation of Poles to take part in the 2019 European election was due to a change in Poles' attitudes towards the EU: that after 2014 they became increasingly 
interested in the EU and its problems, had greater awareness of how the EU and its election system work, were more positively disposed towards the EU, identified themselves more as Europeans, and had different perceptions of the European Parliament. ${ }^{4}$

My second research hypothesis relates to the character of the election campaign itself, that the increased turnout in the 2019 EP election related primarily to a change in the importance attributed to the election by the political parties involved. In the history of Poland's EU membership, 2019 was the first year ever in which both a European parliamentary election and a national parliamentary election were held. The proximity of the two (the EP election in May and the national election in October) meant that the ruling party and opposition parties treated the EP election as a test before the national election in the autumn, almost as a kind of 'first round' of that election. ${ }^{5}$ This caused a far-reaching 'nationalisation' of the European election campaign, with it being dominated by national issues.

In both the spring and the autumn, PiS's campaign strategy focused on domestic issues, and involved making numerous promises of social benefits. The party's project for turning Poland into a prosperous, Western-style welfare state - put together for the domestic contest but presented to voters in February 2019, before the European election - proved effective in attracting voters to the ballot box.

At the same time, with its intensive social narrative, PiS managed to impose its view of the EP election campaign on rival political groupings. In earlier such campaigns, in which the pro-integration groupings forming the government set the tone, domestic issues played a lesser role (Osiński, Pytlik 2016, pp. 85, 88, 94-95).

Moreover, given the strong motivation of all parties to confirm their political clout in the 2019 European election, that is, just half a year before the national parliamentary election, it was evident that they engaged more resources than previously in the European election campaign, giving it a bigger presence in the media.

\section{Methodology of the research}

The time frame for the analysis was established as 2004-2019, such that it encompassed all four EP elections in which Polish citizens have taken part. In operationalising the research, use was made of quantitative data from the State Election Commission

${ }^{4}$ As to the other elements of Europe salience theory, it should be explained that the effect of the location of EU institutions on voter turnout for European elections was not deemed to be a relevant variable, since the only EU institution with its headquarters in Poland is Frontex (since 2017). While Poland has one of the most highly developed agricultural sectors of any EU country, in the years 2014-2018 employment in agriculture fell from 16.4\% to 14.9\% (Szczukocka, 2012, p. 116; GUS 2015, GUS 2019). Further, despite the large number of beneficiaries of the Common Agricultural Policy in Poland, participation in EP elections had remained at a stable low level since 2004. And so, the impact of this variable on the turnout for the European election in 2019 was also marginal. The euro-scepticism of the ruling party PiS, and restrained European narration in the public media, should be deemed factors that would restrict, not increase, the turnout for European elections.

${ }^{5}$ During the PiS convention in March 2019, the chairman, Jarosław Kaczyński, clearly emphasised his party's position on this issue, stating that the European election and the national election "are essentially one election where what's at stake is the future of Poles and Poland" (Bodalska, 2019). 
[Państwowa Komisja Wyborcza - PKW] and the European Parliament on election turnout and the distribution of support gained by particular political parties. A key source of materials for this study was the results of reliable public opinion surveys conducted at the national level by the Public Opinion Research Centre [Centrum Badania Opinii Społecznej-CBOS], and at the European level by Eurobarometr. These included pre-election and post-election surveys that showed Poles' attitudes towards European integration and Poland's membership in the EU and towards other EU bodies, as well as studies concerning evaluations of the social programmes implemented in Poland and of the situation on the Polish labour market. The analysis involved comparing Poles' opinions on the subject of the EU and the domestic economic situation from 2014 and 2019 in order to verify whether in that period any clear changes had taken place in perceptions of the EU that could explain the dramatic increase in the turnout for the EP election in 2019. The results of the public opinion surveys on Poles' feelings were then assessed in relation to social indicators covering the most important macroeconomic data (unemployment, GDP). This made it possible to place the opinions of Poles within a specific socio-economic reality, and to at least partially explain how the positions they expressed may have been conditioned. Here a basic source of information was data made available by Eurostat. This analysis of the surveys and statistical data was supplemented by references to the literature on the subject. The theoretical foundations of the research were second-order election theory and Europe salience theory.

\section{Attitudes of Poles towards the EU}

In the first part of this article, in accordance with the Europe salience theory, I will verify the hypothesis that the almost $100 \%$ increase in voter turnout in Poland for the EP election in May 2019 over the EP election in 2014 was due to a significant increase during the period under analysis of Poles': interest in the EU, positive attitudes towards the EU, awareness of how the EU and its election system operate, self-identification with the EU (European identity), and changing perceptions of the European Parliament. Here, then, I will show how in the years 2014-2019 Poles' attitudes towards the EU changed.

It should be emphasised that the years 2014-2019 were a period of lasting euro-scepticism within the Union, of complex processes of disintegration, and of a renewal of nationalisms and xenophobic attitudes in the aftermath of the economic and migration crises.

Given that Poland felt the effects of these crises only to a negligible degree, one may venture a further hypothesis: that, overall, Poles were above the EU average in terms of favouring EU integration in the years 2008-2018. After 2008, Poland was the only EU Member State that did not experience negative economic growth (Eurostat, 2019). After a short economic downturn in 2012-2013, as from 2014 Poland posted some of the highest economic growth results in the whole European Union. This favourable economic situation translated into the situation on the labour market. Since 2014, Poland has had single-digit unemployment. ${ }^{6}$ According to Eurostate, in 2019 that figure was

${ }^{6}$ In the years 2002-2004, unemployment in Poland remained at a level of 20-19\%, but then fell to $7 \%$ by 2008 . In the years $2009-2013$ it oscillated around $10 \%$, and thereafter began to fall once again (Eurostat, 2020). 
$3.3 \%$ - the lowest unemployment rate ever recorded in the country. This certainly affected assessments of how the labour market in Poland was functioning. Between 2014 and 2019, the percentage of people who believed the labour market situation was good grew from 4\% to 51\%. And while in 2014 no survey respondent indicated that the situation on the Polish labour market was very good, in 2019 such a view was expressed by $7 \%$ of Poles (Boguszewski, 2019, p. 2). As a result of the conservative policies of the PiS government, Poland refused to accept migrants under the Union quota system negotiated in 2015, and no refugees from the Middle East ended up in Poland. Further, Poland's geographic location away from the migration routes from the Arab lands meant that, for Poles, the migration crisis of 2015 remained just a media experience.

Diagram 1. Trust of Poles in the European Union in the years 2008-2018

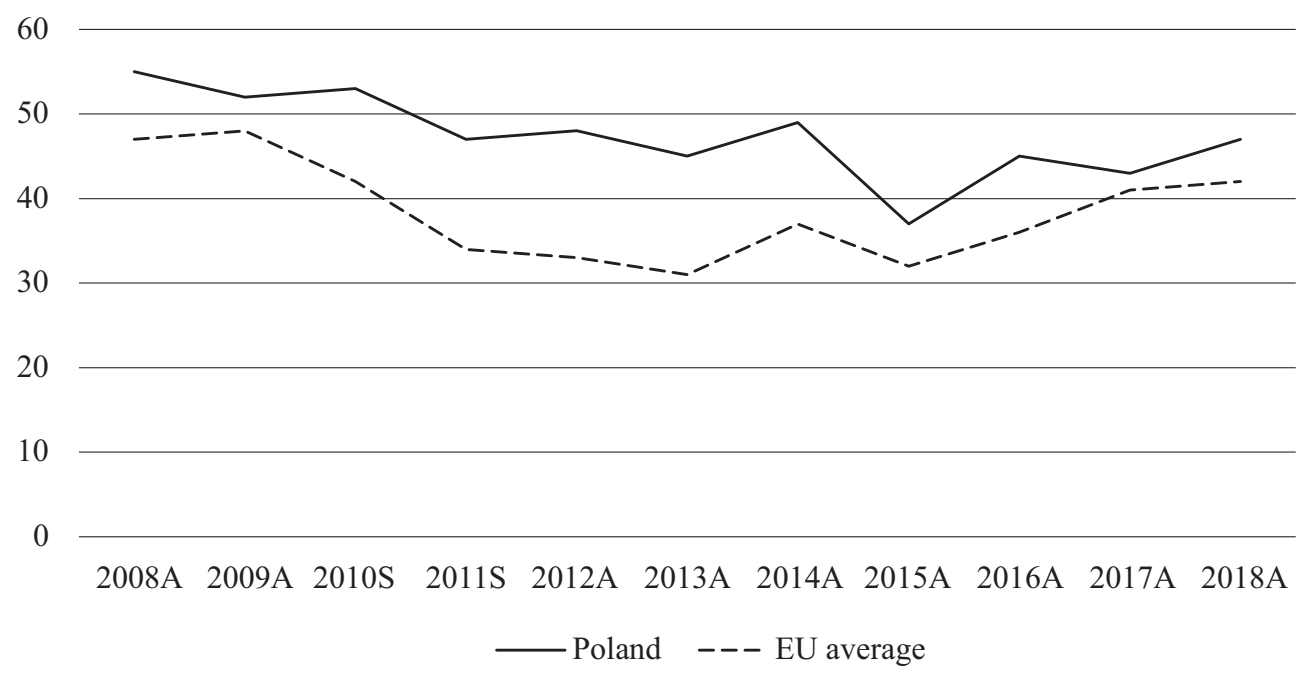

Source: Own study based on Eurobarometr data (A - autumn, S - spring).

Eurobarometr data showing Poles' trust in the EU and the image of the EU in the eyes of Poles confirm the hypothesis of their having higher than average positive attitudes towards the Union, including during the decade of EU crises. From 2008 to 2019, the positive image of the EU in the eyes of Poles averaged 10 percentage points higher than the EU average (and in 2014 that difference went up to 17 percentage points). From Eurobarometr studies, it also results that Poles' trust in the EU during the first years of the economic crisis (2008-2010) went down only slightly. Only in the years that followed was there a gradual decline. In 2013, when the Polish economy finally felt the effects of the economic crisis, Poles' trust in the EU was already 10 percentage points lower than in 2008. A further significant drop in trust occurred in the autumn of 2015 - the epicentre of the migration crisis. At that time, Poles' trust in the EU reached its lowest value - only $37 \%$ of Poles believed the EU was reliable. In 2016, Poles' trust in the EU was rebuilt. Yet, in the whole period under study, i.e. from 2014-2018/2019, no radical increase was seen in Poles' trust in the EU or in the EU's image in Poland that could explain the mass interest Poles showed in the EP election of 2019. While it is true that the EU's image 
among Poles was higher than the EU average during this period, it was stable. From 2014 to 2019, the EU's image among Poles improved by only 2 percentage points (from $52 \%$ to $54 \%$ ). In turn, in the autumn of 2018 Poles' trust in the EU was 2 percentage points lower than in the autumn of 2014 (Eurobarometr, 2020).

Diagram 2. Trust of Poles in the European Parliament in the years 2004-2019

70

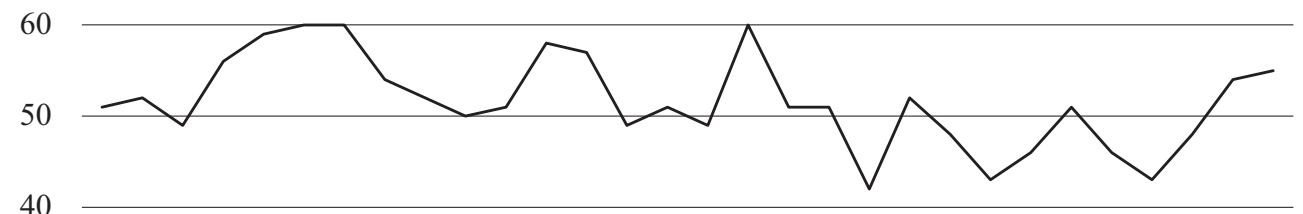

40

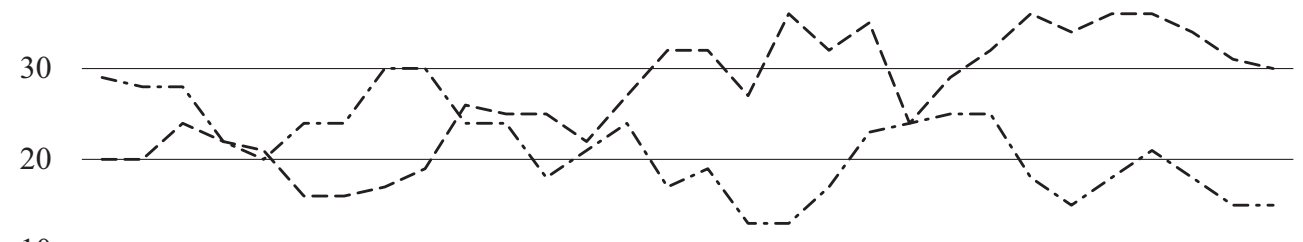

10

0

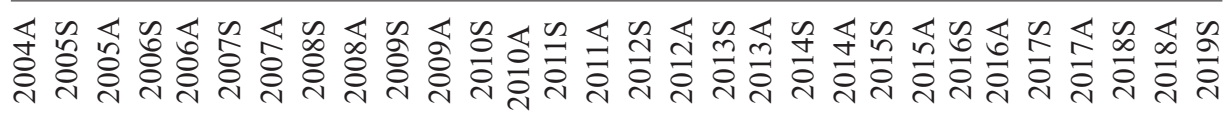

— Tend to trust $\quad$ - - - Tend not to trust $\quad$-.-- Hard to say

Source: Own study based on Eurobarometr data (A - autumn, S - spring).

The hypothesis of change of Polish perceptions of the European Parliament is difficult to prove directly using the empirical data available. Indirectly, one can draw on Eurobarometr studies that show Poles' level of trust in the EP. Here a significant change can really be seen. Between the spring of 2014 and the spring of 2019, Poles' trust in the EP grew by 13 percentage points (from $42 \%$ to $55 \%$ ). Throughout the period of the survey, that is from 2004-2019, the level of trust fluctuated by 20 percentage points, with the lowest recorded result being $42 \%$, in the spring of 2014, and the highest $60 \%$ (in 2007 and the autumn of 2012). Considering that in the spring of 2009 $50 \%$ of Poles declared that they trust the European Parliament but only one quarter of all Poles took part in the EP election, it is difficult to see how the growth in that indicator to $55 \%$ by the spring of 2019 could have been a decisive factor in doubling the turnout (Eurobarometr, 2020).

Furthermore, Poles' increasing interest in European issues from the autumn of 2014 to the spring of 2019 was also of minor importance. The number of people who declared they were frequently interested in European issues went up by a mere 2 percentage points (from $11 \%$ to $13 \%$ ), and the same was the case with people who declared an occasional interest in European issues (from 47\% to 49\%) (Eurobarometr, 2020). 
As to self-evaluation of knowledge about the EU, from the spring of 2014 to the spring of 2019, this figure rose among Poles from $71 \%$ to $79 \%$, putting Poland in second place, just after Sweden (Eurobarometr 2020). When Poles' knowledge about the EU was verified by a question on the character of EP elections (whether they are direct elections), in both 2014 and $201981 \%$ of respondents answered correctly (Eurobarometr, 2020).

Significant changes took place, however, regarding Poles' identification with the EU. CBOS surveys showed that, from 2014 to 2019, Poles' identification as Europeans became stronger. In 2014, $43 \%$ of Poles declared that they identified themselves as Europeans (with $41 \%$ identifying themselves as Poles first, and as Europeans second). In 2019, 56\% of Poles considered themselves Europeans, a 13 percentage points increase in 5 years (with $52 \%$ declaring this to be a secondary identity after their national identity) (Roguska, 2019, p. 22). European identity was declared more often by people with higher education, living in a large city, holding a managerial position at work, having specialist professional qualifications or running their own business, by pupils and university students, and more often by women than men (Roguska, 2019, p. 22).

Between 2014 and 2019, growth was also seen (from 41\% to 50\%) in the number of people who held the opinion that Europe should unite still further (Roguska, 2019a, p. 20). Since 2014, support for Poland's membership in the EU has remained at a level of more than 80\%. In 2019, it reached its highest level ever-91\% (Roguska, 2019, p. 2). At that time, $78 \%$ of respondents declared that EU membership brought Poland more gains than losses (a 16 percentage points increase over 2014). In the personal dimension, 57\% of those surveyed saw more benefits in EU membership (a 14 percentage points increase) (Roguska, 2019, p. 3).

At the same time, $85 \%$ of respondents were of the opinion that Poland's presence in the Union had a beneficial impact on the economy (an increase of 9 percentage points from 2014 to 2019). These opinions can be treated as deriving from the good economic situation in Poland (economic growth in the period surveyed ranged from $3.3 \%$ to $5.1 \%$ ) (Eurostat, 2019). In turn, in 2019, 78\% of respondents believed that integration had beneficial effects on the material conditions of life in Poland. This was 25 percentage points more than in 2014 (Roguska, 2019, p. 12).

Since acceding to the EU, Poland has grown dynamically. Thanks to EU funds, it has significantly expanded its road and rail networks. In 2019, 90\% of those surveyed felt that the changes in this respect had been positive. This result was 7 percentage points higher than in 2014 (Roguska, 2019, pp. 12-13).

\section{The 2019 European Parliament election campaign in Poland}

The main EP election campaign slogan of PiS, unveiled at the end of 2018, was "Poland - the Heart of Europe" ["Polska sercem Europy"], which appealed to Poles' feelings of national pride, and suggested that, thanks to the efforts of the ruling party, Poland would be setting the tone in European politics. PiS's election programme was revealed in February 2019 during a convention at which the party leader, Jarosław Kaczyński, announced a plan to expand the state's social policy - the plan became known as 
'Kaczyński's Five', a set of five bills covering investments for the benefit of families, the young, the elderly, the infirm, the labour market, and infrastructure.

It should be emphasised that a 'five' is universally perceived as a very good mark, given out to the best students in the Polish educational system. In this way, in promoting the bills, PiS strategists resorted to a technique of social engineering - with the phrase 'Kaczyński's Five' they sent a subconscious message that their programme deserved the highest rating from voters.

The first point in the programme concerned the family. It announced a further expansion of the $500+$ benefit, a family benefit paid for each child as from 1 July 2019. ${ }^{7}$ Young people were promised the introduction of zero personal income tax (PIT) for those below 26 years of age and a reduction in employee PIT for all. Retirees and pensioners were told they would receive a thirteenth monthly payment in the amount of 1,100 PLN. The final point in 'Kaczyński's Five' was a promise to restore cancelled bus connections between small towns and rural areas ("Piatkę Kaczyńskiego"..., 2019; Bochen, 2019). Non-motorised elderly people and women who had to travel from rural areas to local urban centres had been hit particularly hard by the reductions made in public transport in less urbanised areas in the 2010s.

This programme had nothing to do with the European Union. It consisted solely of the type of social postulates that build capital in domestic elections. In the context of the ruling party lumping the EP and national parliamentary elections together, this must be seen as a deliberate tactic. Focusing the narrative on internal matters was to serve PiS' strategic goals, to help mobilise its electorate so as to confirm its leading position in the country in the European election. PiS sought to create interest in the EP election among its supporters (mainly seniors and rural inhabitants with secondary and vocational education) for whom the EU had previously been a distant institution, and the matters it dealt with difficult and incomprehensible. PiS tends to win votes mainly among inhabitants of rural areas and smaller towns who are more concerned about Poland and its domestic problems than they are about the EU. In such circles, cosmopolitan attitudes are present to a much lesser degree than they are among supporters of the leading opposition party, Civic Platform (PO).

In March 2019, just one month after the announcement of 'Kaczyński's Five', PiS held another convention at which it announced a European Declaration consisting of 12 points. This was a symbolic reference to the 12 stars on the EU flag. For PiS politicians, the key elements of the declaration were to effect a return by the EU to the values proclaimed by its founding fathers; to defend parents' right to raise their children as they see fit; to use the EU forum to protect the interests of Polish farmers and to guarantee equal treatment for Polish businesses; and to have a new EU budget approved that was favourable for Poland. Other PiS European postulates included taking care of the safety and protection of the EU's external borders; acting to achieve energy independence for Poland and Europe; fighting for equal treatment for consumers throughout Europe and ensuring they have access to goods of the same quality; acting to eliminate double standards in the treatment of EU Member States; striving to secure Poland's interests in Europe's climate policy; developing a strong cohesion policy as the basis for rapid, solidary

${ }^{7}$ Since 1 April 2016, a family benefit in the amount of 500 PLN monthly (approx. 110 EUR) had been paid in Poland for a second and every subsequent child. 
growth of the EU; granting EU aid for refugees in conflict locations; and opposing illegal immigration (Bodalska, 2019). It must be emphasised that, in terms of social perceptions, the intensive promotion of 'Kaczyński's Five' throughout the election campaign quickly and effectively overshadowed the above references to the EU in PiS's election programme.

In the PiS campaign, the European thread also appeared in the context of frightening Poles with the prospect of having to join the eurozone should the European Coalition $[\text { Koalicja Europejska }-\mathrm{KE}]^{8}$ win the European election. The idea of introducing the euro does not enjoy wide support in Polish society. Whereas in 2002 64\% of Poles approved of accepting the euro, after 2010 - the outbreak of the crisis in the eurozone - that percentage dropped to $22 \%$. By the autumn of $2018,71 \%$ of Poles were against the common currency (Roguska, 2018, pp. 5-7).

In this way, PiS came up with a programme designed to unite many social groups: the young, the elderly, families. The European election campaign became monopolised by promises that referred mainly to domestic politics, including social policy, with regard to which the EU's competences are only coordinative.

In this situation, the European Coalition focused on ensuring voters that it would not take away the benefits granted to them by PiS, even trying to add additional ideas - no easy task given PiS's already expansive social package. In KE's campaign, Community issues mainly concerned the dispute over who would best represent Poland in the EU. KE tried to frighten voters with PiS's alleged intention of staging a Polexit, and accused the government of incompetence in negotiating the EU budget for 2021-2027. It promised to negotiate 100 billion PLN more for Poland in a new EU perspective, and to allocate those funds for health care, the labour market and agriculture. Against KE's narrative about Polexit, from the Polish president's circle came an idea to enshrine Polish membership in the EU and NATO in the Polish constitution (Kolanko, 2019; Osiecki, 2019).

In turn, the flagship postulate in the campaign run by a new political formation - Spring [Wiosna], founded by Robert Biedroń on 3 February 2019 - was to reduce the influence of the Roman Catholic Church in Polish politics and society (abolishing religion in schools, abolishing the Church Fund, taxing the Church). These campaign promises as well solely concerned domestic issues (Osiecki, 2019).

It must be emphasised that, overall, Poles accepted the programme to expand the welfare state presented in 'Kaczyński's Five'. According to CBOS surveys, Poles' support for zero personal income tax (PIT) for those up to the age of 26 was $73 \%$; support for reducing employment costs by increasing the costs of earning revenue and lowering PIT for employees was 77\%; support for the child care benefit of 500 PLN from the "Family 500+" programme for each child was 75\%; support for restoring local bus connections was $83 \%$; support for a one-off 'thirteenth month' of 1,100 PLN for retirees and pensioners was $84 \%$. Of all the reforms proposed, Poles considered the most important to be expanding the family benefit paid for every child (31\%), the one-off thirteenth pension payment (21\%), and lowering employment costs (19\%). Less weight was given

8 The European Coalition is an election coalition established on 24 February 2019 for the upcoming European parliamentary election, consisting of the Civic Platform (PO), the Democratic Left Alliance (SLD), the Polish People's Party (PSL), The Greens [Zieloni], and Modern [Nowoczesna]. 
to introducing zero PIT for persons up to 26 years of age (11\%), and restoring local bus connections (9\%). 45\% of Poles stated that Poland could afford 'Kaczyński's Five'; this group was dominated by people with only lower education (up to high school) with a low or average income (below 1,800 PLN monthly) ${ }^{9}$ living in rural areas and small towns (of less than 100,000 inhabitants), and by those above the age of 45 . In turn, $38 \%$ of Poles responded that the Polish state could not afford such an expansive social package. These were mainly people with higher education, earning at least 2,500 PLN per month, ${ }^{10}$ living in large cities (of above 100,000 inhabitants), and people below the age of 45 (Omyła-Rudzka, Roguska, 2019, pp. 2, 6).

In April 2019, 3 years after the introduction of the 500+ benefit, the pro-family policy of the Polish state was supported by $62 \%$ of Poles. Prior to the programme, only $16 \%$ of Poles had a favourable opinion about the state's family policy (Bożewicz, 2019, pp. 1-2).

This concentration by politicians of all formations on domestic issues during the European election set off a chain reaction: the media gave the election more coverage than in the past ('Kaczyński's Five' was the subject of lively discussions in all the media), and this in turn led to Poles taking a much greater interest in the election. In May 2014, 40\% of Poles declared that they were interested in EP elections; in May 2019 that figure was 63\% (Roguska, 2019b, pp. 1-2). In the years 2009-2018, the percentage of people who considered European elections very important had never exceeded 25\%. In April 2019, $42 \%$ of Poles said such elections were very important. This was the highest evaluation in this respect since Poland's accession to the EU (Cybulska, Pankowski, 2019, p. 3).

The results of a CBOS survey conducted in June 2019 showed that PiS' 'domestic' campaign strategy in the European election had been successful. PiS managed to mobilise its electorate, who in previous years had been very reluctant to vote in European elections. 56\% of PiS voters took part in the EP election in 2014. As many as $45 \%$ stayed home. In 2019, there was a mass mobilisation of PiS voters. $85 \%$ of those who supported the ruling party voted. Only 15\% ignored the European election (compare Table 1).

Table 1

Participation in the elections to the European Parliament in the years 2004-2019 by supporters of particular political parties (in \%)

\begin{tabular}{|c|c|c|c|c|c|c|c|c|}
\hline \multirow{3}{*}{ Electorate of political parties } & \multicolumn{8}{|c|}{ Did you vote in the election to the European Parliament? } \\
\hline & \multicolumn{2}{|c|}{2004} & \multicolumn{2}{|c|}{2009} & \multicolumn{2}{|c|}{2014} & \multicolumn{2}{|c|}{2019} \\
\hline & yes & no & yes & no & yes & no & yes & no \\
\hline PiS (Law and Justice) & 72 & 28 & 67 & 33 & 56 & 45 & 85 & 15 \\
\hline PO (Civic Platform) & 58 & 41 & 68 & 32 & 64 & 36 & 86 & 14 \\
\hline New Right J. Korwin-Mikke & - & - & - & - & 71 & 29 & - & - \\
\hline $\begin{array}{l}\text { SLD (Democratic Left Alliance), in the } \\
2019 \text { election together with New Greens }\end{array}$ & 64 & 36 & 64 & 36 & 63 & 37 & 84 & 16 \\
\hline LPR (League of Polish Families) & 59 & 41 & - & - & - & - & - & - \\
\hline PSL (Polish People’s Party) & 41 & 59 & 48 & 52 & 61 & 39 & 78 & 22 \\
\hline Undecided & 44 & 56 & 53 & 47 & 49 & 51 & 59 & 41 \\
\hline Not voting in parliamentary elections & 9 & 91 & 22 & 92 & 22 & 92 & 13 & 87 \\
\hline
\end{tabular}

Source: Based on Cybulska, 2004, p. 3; Roguska, 2009, p. 6; Cybulska, 2014, p. 6; Pankowski, 2019 , p. 7.

\footnotetext{
91,800 PLN is about 400 EUR.

102,500 PLN is about 550 EUR.
} 
The European Coalition also managed to mobilise its electorate. In 2019, $86 \%$ of Civic Platform supporters (compared with $64 \%$ in 2014), and $84 \%$ of Democratic Left Alliance supporters (compared with $63 \%$ in 2014), and 78\% of Polish People's Party supporters (compared with 61\% in 2014) took part in the EP election. Surveys also show that a crucial factor in motivating people to vote for European Coalition was their dislike of PiS (17\% of European Coalition voters declared that their desire to get PiS out of power was their main motivation for taking part in the EP election). In the case of PiS supporters, only $5 \%$ of respondents indicated that their dislike of Civic Platform and European Coalition motivated them to vote.

PiS' campaign strategy proved very effective. PiS won the election with $45.38 \%$ of the vote, which translated into 27 seats in the European Parliament. The European Coalition came in second, with $38.47 \%$ of the vote (22 seats). Robert Biedron's Spring [Wiosna] came in third, with $6.06 \%$ of the vote ( 3 seats). The other parties running in the election failed to cross the electoral threshold (PKW, 2019).

The success of Spring, a political grouping set up less than 4 months before the election, provided confirmation - in line with second-order election theory - of yet another regularity characteristic of EP elections. Because European elections do not lead to the formation of a 'euro-government', voters do not feel under any pressure to vote strategically; on the contrary, they have the comfort of being able to vote according to their own ideological preferences. This is to the advantage of small parties (Majcherkiewicz, 2018, p. 173). The outright anticlericalism on which Biedron based his campaign appealed to certain Polish voters, and carried Spring into third position behind PiS and KE.

\section{Conclusions}

The first hypothesis examined, that a change in Poles' attitudes towards the EU was the main cause of the increased Polish voter turnout in the 2019 EP election, was disproved with regard to most of the variables involved. From 2014 to 2019, the EU's image among Poles improved by only 2 percentage points (from 52\% to 54\%), and Poles' trust in the EU declined by 2 percentage points as well. Nor did the analysis of the level of trust Poles have in the European Parliament explain their increased participation in the EP election in 2019. If we compare their level of trust in the EP in the years in which previous elections were held, i.e. in 2004, 2009 and 2014, the highest level of trust in the European Parliament among Poles was in 2009, at 50\%. At that time, the Polish election turnout was just below 25\%. It is difficult to see, then, how the growth in Polish trust in the EP to $55 \%$ by the spring of 2019 could have been a decisive factor in doubling the turnout. Also, between 2014 and 2019, the number of people declaring frequent or occasional interest in European affairs rose by a mere 2 percentage points. The level of knowledge about EP elections did not change. In the period studied, however, there was significant growth in the extent to which Poles identified as Europeans - by 13 percentage points. The analysis conducted also shows that, between 2014 and 2019, the number of Poles who had a favourable view of Poland's membership in the EU increased significantly, both at the macro scale (when assessing the impact of membership on overall 
economic growth) and individually (when assessing the impact of membership on improving the living conditions of families and individuals). Here, that growth fluctated from 9 to 25 percentage points. Poles willingly attributed the improvement in the overall and their household economies to EU membership.

As to the second hypothesis connecting the increased turnout for the 2019 EP election to the fact that the election was held half a year before a strategic national parliamentary election, my analysis shows that this was the factor that most strongly affected voter behaviour. For the political parties involved, the 2019 European election became a priority, for it allowed them to check their support ahead of the national election to be held in the autumn. A natural consequence of this was for them to focus on internal matters in their election programmes. European issues remained in the background throughout the EP election campaign, while all the parties engaged a lot of time and resources in order to mobilise their supporters.

By employing a domestic rhetoric, PiS effectively drew Poles to the ballot box. PiS was the first Polish political formation after 1989 to put forward a cohesive programme of universal social transfers, offering citizens a vision of a prosperous, Western-style welfare state. During the campaign, it made skilful use of areas of public life that had been neglected for years (Gabryszak, 2019). An analysis of the data shows that that vision held great appeal for Polish people. The EP election ceased to be something abstract; rather than platitudes about the need to take integration forward such as politicians had declared in previous campaigns, voters were given concrete proposals for reforms that could directly affect their quality of life here and now.

And importantly, PiS began to make good on its campaign promises before the vote. Three weeks before the date of the election on 26 May 2019, the 'thirteenth month' salary was paid to retirees, and on 26 April 2019 legislation introducing the 500+ benefit in amount of 500 PLN monthly for every child was adopted (Osiecki, 2019; Ustawa z dnia 4 kwietnia 2019 r....; Ustawa z dnia 26 kwietnia 2019 r....); In this way, PiS mobilised that part of its electorate which the previous lofty phrases about European unity had failed to reach. PiS responded to the demands of ordinary citizens who increasingly felt the need for a greater share in the benefits of economic growth.

Supporters of European Coalition, more pro-EU by nature, were also motivated to take part in the EP election. They treated it as a good occasion to hold up a red card to the politicians of PiS who, since 2015, had departed from the principle of the apolitical nature of the civil service and had weakened the independence of institutions exercising horizontal control over the legislative and executive branches of the state (by violating the principles of the independence of the Constitutional Tribunal and the Supreme Court and the impartiality of the public media).

\section{Bibliography}

2019 European elections results, https://election-results.eu/, 22.08.2019.

Aksztejn W. (2006), Racjonalność wyborcy a paradoks partycypacji. Znaczenie instrumentalnej motywacji dla wyjaśnienia absencji wyborczej w 2005 r., „Decyzje” nr 5.

Bochen D., „Piatka Kaczyńskiego”. Jakie propozycje znalazty się w obietnicach PiS i kiedy zostana wprowadzone?, „money.pl” z dnia 19.03.2019 r., https://www.money.pl/gospodarka/piatka- 
kaczynskiego-jakie-propozycje-znalazly-sie-w-obietnicach-pis-i-kiedy-zostana-wprowadzone-6360749894059649a.html, 04.09.2019.

Bodalska B. (2019), Europejska deklaracja PiS, EUROACTIV.PL, z dnia 11.03.2019 r., https://www. euractiv.pl/section/demokracja/news/europejska-deklaracja-pis/, 05.05.2020.

Boguszewski R. (2019), Sytuacja na rynku pracy w ocenach i doświadczeniach Polaków, CBOS, Komunikat z badań, nr 51.

Bożewicz M. (2019), Program Rodzina 500 plus po trzech latach funkcjonowania, CBOS, Komunikat z badań, $\mathrm{nr} 52$.

Cybulska A. (2004), Głosujący i niegłosujący o swych decyzjach w wyborach do Parlamentu Europejskiego - analiza powyborcza, CBOS, Komunikat z badań, nr 114.

Cybulska A. (2014), Wybory do Parlamentu Europejskiego w powyborczych deklaracjach Polaków, CBOS, Komunikat z badań, nr 96.

Cybulska A., Pankowski K. (2019), Chcemy chodzić na wybory - deklaracje o uczestnictwie i ocena rangi, CBOS, Komunikat z badań, $\mathrm{nr} 67$.

Cześnik M., Kwiatkowska A. (2017), Uczestnictwo wyborcze w 2014 i 2015 roku, w: Demokratyczny Audyt Polski, 2: Demokracja wyborcza w Polsce 2014-2015, red. R. Markowski, J. Wasilewski, Biuro Rzecznika Praw Obywatelskich, Warszawa, pp. 27-48.

Donatella M. Viola (2015), European Parliament Elections Theories, w: Routledge Handbook of European Elections, ed. M. Viola Donatella, Routledge, London, pp. 39-48.

Eurobarometr (2020), https://ec.europa.eu/commfrontoffice/publicopinion/index.cfm/General/index, 15.01.2020.

Eurostat (2019), Real GDP growth rate - volume, Percentage change on previous year, https:// ec.europa.eu/eurostat $/ \mathrm{tgm} / \mathrm{table} . \mathrm{do} ? \mathrm{tab}=$ table $\&$ init $=1 \&$ language $=$ en \&pcode $=$ tec $00115 \& \mathrm{plug}$ in $=1,9.12 .2019$.

Eurostat (2020), Unemployment by sex and age - annual average, https://appsso.eurostat.ec.europa.eu/ nui/submitViewTableAction.do, 09.03.2020.

Gabryszak R. (2019), The evolution of the positions on social issues of major political parties in Poland. Comparative analysis of the election programs of Platforma Obywatelska (Civic Platform) and Prawo i Sprawiedliwość (Law and Justice) from 2007, 2011 and 2015, "Przegląd Politologiczny", nr 4.

Gasser F., David vs. Goliath of voter turnout: Why is the participation in EU elections so low?, 29.05.2019, https://blogs.eurac.edu/eureka/david-vs-goliath-of-voter-turnout-why-is-the-participation-in-eu-elections-so-low/, 03.05.2020.

Grzelak P., Cześnik M. (2007), Frekwencja wyborcza w Polsce w latach 1990-2007, w: Kampania społeczna ,Zmień kraj. Idź na wybory”. Raport o przebiegu kampanii i rekomendacje na przyszłość, red. J. Bełdowski, P. Chylińska, Warszawa, pp. 4-11.

GUS (2015), Rocznik Statystyczny Rzeczypospolitej Polskiej, Warszawa.

GUS (2019), Rocznik Statystyczny Rzeczpospolitej Polskiej, Warszawa.

Hix S., Marsh M. (2007), Punishment or Protest? Understanding European Parliament Elections, "The Journal of Politics", vol. 69, no. 2.

Hyndle-Hussein J. (2014), Litwa wybiera prezydenta, „Analizy OSW” z dnia 14.05.2014 r., https:// www.osw.waw.pl/pl/publikacje/analizy/2014-05-14/litwa-wybiera-prezydenta, 9.01.2020.

Kolanko M. (2019), Kampania do PE na ostatniej prostej, „Rzeczpospolita” z dnia 12.05.2019 r., https://www.rp.pl/Wybory-do-PE/190519866-Kampania-do-PE-na-ostatniej-prostej.html, 09.09.2019.

Majcherkiewicz T. (2018), Wybory regionalne jako wybory drugorzędne a perspektywa rządzenia wielopoziomowego, „Przegląd Politologiczny”, nr 1.

Marsh M. (1998), Testing the Second-Order Election Model after Four European Elections, "British Journal of Political Science", vol. 28, no. 4. 
Omyła-Rudzka M., Roguska B. (2019), Reakcje społeczne na rozwiązania tzw. Nowej Piątki PiS, CBOS, Komunikat z badań, nr 45.

Osiecki G. (2019), Pięć frontów kampanii do Parlamentu Europejskiego, „dziennik.pl” z dnia 6.05.2019 r., https://wiadomosci.dziennik.pl/polityka/artykuly/597141,kampania-wybory-parlament-europejski.html, 09.09.2019.

Osiński J., Pytlik B. (2016), The 2014 European Parliamentary Election in Poland: The Evaluation of the Challenges to the European Union, "Studia z Polityki Publicznej", nr 4(12).

Pankowski K. (2019), Decyzje w wyborach do Parlamentu Europejskiego. Przyczyny absencji wyborczej, CBOS, Komunikat z badań, nr 94.

„Piątę Kaczyńskiego” popieraja tylko wyborcy PiS? Najnowszy sondaż, „Wprost” z dnia 15.04.2019 r., https://www.wprost.pl/kraj/10208300/piatke-kaczynskiego-popieraja-tylko-wyborcy-pisnajnowszy-sondaz.html, 04.09.2019.

PKW (2019), Wybory do Parlamentu Europejskiego 2019, Wyniki głosowania Polska, https://wybory. gov.pl/pe2019/pl/wyniki/pl, 09.09.2019.

PKW (2020), https://pkw.gov.pl/wybory-i-referenda/wybory-prezydenta-rzeczypospolitej-polskiej/ wybory-prezydenta-rp-w-2020ampnbspr, 04.02.2020.

Rachwał M. (2017), Znikajacy wyborcy - partycypacja w wyborach do Parlamentu Europejskiego, w: Wspótczesne oblicza władzy politycznej. Wybrane zagadnienia, red. M. Rachwał, Wydawnictwo Naukowe WNPiD UAM, Poznań, pp. 61-73.

Results of the 2014 European elections, http://www.europarl.europa.eu/elections2014-results/en/turnout.html, 22.08.2019.

Roguska B. (2009), Wybory do Europarlamentu w powyborczych deklaracjach Polaków, CBOS, Komunikat z badań, $\mathrm{nr} 110$.

Roguska B. (2018), Polska w Unii Europejskiej, CBOS, Komunikat z badań, nr 166.

Roguska B. (2019), 15 lat członkostwa Polski w Unii Europejskiej, CBOS, Komunikat z badań, nr 59.

Sondaż powyborczy 2014. Wybory do Parlamentu Europejskiego w 2014 r. Podsumowanie analityczne, Dział Badania Opinii Publicznej, Bruksela 2014.

Szczukocka A. (2012), Poziom i dynamika zmian zatrudnienia $w$ sektorze rolnym $w$ Polsce na tle innych państw Unii Europejskiej, „Zeszyty Naukowe SGGW w Warszawie - Problemy Rolnictwa Światowego", vol. 12(27), nr 2.

Sześciło D., Cześnik M., Markowski R. (2013), Masz głos, Masz wybór. Obywatele i wybory, Raport Fundacji Batorego, Fundacja im. Stefana Batorego, Warszawa.

Ustawa z dnia 26 kwietnia 2019 r. o zmianie ustawy o pomocy państwa w wychowywaniu dzieci oraz niektórych innych ustaw, Dz. U. RP z dn. 17 maja 2019 r., poz. 924.

Ustawa z dnia 4 kwietnia 2019 r. o jednorazowym świadczeniu pieniężnym dla emerytów i rencistów w 2019 r., Dz. U. RP z dn. 24 kwietnia 2019 r., poz. 743.

\section{O wpływie krajowego cyklu wyborczego na poziom frekwencji w wyborach do Parlamentu Europejskiego. Kazus Polski}

\section{Streszczenie}

Celem artykułu jest zdiagnozowanie przyczyn wzrostu zainteresowania Polaków wyborami do Parlamentu Europejskiego w 2019 r. Między 2014 r. a 2019 r. nastąpił wzrost partycypacji Polaków w eurowyborach z 23,83\% do 45,68\%. Posiłkując się teorią oddziaływania Europy (Europe salience theory) oraz teorią wyborów drugiego rzędu (second-order elections) Autorka starała się ustalić czy to zmiany w postawach Polaków wobec Unii Europejskiej doprowadziły między 2014 r. a 2019 r. do niemal podwojenia frekwencji w wyborach do Parlamentu Europejskiego, czy efekt ten należy głównie 
przypisać cyklowi wyborczemu tj. skumulowaniu w jednym roku europejskich i krajowych wyborów parlamentarnych. W badaniu przeprowadzono analizę danych sondażowych (CBOS, Eurobarometr) oraz danych statystycznych, przeanalizowano też przebieg kampanii do Parlamentu Europejskiego.

W toku przeprowadzonej analizy wykazano, że w latach 2014-2019 nie doszło do istotnych zmian w postrzeganiu Unii Europejskiej i jej instytucji przez Polaków, które mogłyby tłumaczyć radykalny zwrot zainteresowania eurowyborami. To usytuowanie eurowyborów na kilka miesięcy przed strategicznymi krajowymi wyborami parlamentarnymi miało największy wpływ na zmianę zachowania wyborców. Partie polityczne potraktowały majowe eurowybory jako test poparcia przed jesiennymi wyborami krajowymi, jako quasi I turę wyborów krajowych. Eurokampania była bardzo medialna i koncentrowała się na problematyce krajowej (rozbudowie polskiego państwa dobrobytu). Zapowiedź licznych reform socjalnych przez partię rządzącą oraz chęć wpływu na wynik w „majowej turze” wyborów zmobilizowały ponadprzeciętnie dużo Polaków do aktywnego udziału w eurowyborach.

Słowa kluczowe: frekwencja, wybory, Parlament Europejski, Polska, kampania wyborcza 
